\title{
THE POLICY MODEL FOR SUSTAINABLE COMMUNITY FOREST: A FACTOR ANALYSIS
}

\author{
Tatan Sukwika* and Lidya Fransisca \\ Department of Environmental Engineering, Faculty of Engineering, Sahid University, \\ J1. Prof. DR. Soepomo No.84, RT.7/RW.1, Menteng Dalam, Kec. Tebet, Kota Jakarta Selatan, \\ Daerah Khusus Ibukota Jakarta 12870, Indonesia
}

Received: 3 November 2020, Revised: 30 September 2021, Accepted: 9 October 2021

\begin{abstract}
MODEL OF POLICY FOR SUSTAINABLE COMMUNITY FOREST: A FACTOR ANALYSIS. Developing and maintaining forest sustainably is a way to support sustainable development. From the technical point of view, the sustainability of community forest could be articulated not only based on the three aspects i.e. economic (ECO), social culture (SOC), ecology (EGY), but it could also include dimensions of legal and institutional (LIT), as well as accessibility and technology (ACT). This study aims to determine variables of sustainability dimensions that have a direct positive effect on the sustainability of the community forests (SCF), to identify variables that affect SCF and variables of sustainability dimensions that have a major effect on SCF. This study is aiming for 70 samples of forest farmers' group in Bogor Regency. The respondents were purposively selected based on consideration of the criteria for forest farmer groups namely beginner, intermediate, and advanced. The analysis was conducted based on PSL-SEM tools. Sustainability dimensions of ECO, EGY, LIT, and ACT have a significant positive direct effect on SCF. The mediational hypothesis testing suggested that there is a partial mediation from ECO and EGY to SCF, which is consistent and have a positive value. Based on the coefficient value of the total-effect, among the five dimensions, ecology value was the biggest and the most effect. The policy implies that the ecological aspects considered the importance and strategy. Therefore, the value and productivity of the community forest structure and composition need to be maintained.
\end{abstract}

Keywords: Sustaianable community forest, direct-indirect effect, mediation-total, PLS-SEM

MODEL KEBIJAKAN HUTAN MASYARAKAT BERKELANJUTAN: ANALISIS FAKTOR. Mengembangkan dan memelihara butan lestari merupakan salah satu cara untuk mendukung pembangunan berkelanjutan. Secara teknis, kelestarian butan masyarakat dapat diartikulasikan tidak. hanya dari tiga aspek, yaitu ekonomi (ECO), sosial budaya (SOC), ekologi (EGY), namun juga termasuk dimensi legal dan institusional (LIT), serta aksesibilitas dan teknologi (ACT). Penelitian ini bertujuan untuk. menentukan variabel dimensi keberlanjutan yang berpengaruh langsung positif terbadap kelestarian butan masyarakat (SCF), mengidentifikasi variabel yang mempengarubi SCF dan variabel dimensi keberlanjutan yang berpengaruh dominan terhadap SCF. Penelitian ini menggunakan sampel 70 kelompok tani butan di Kabupaten Bogor sebagai sampel responden dan responden dengan tujuan berdasarkan pertimbangan kriteria kelompok tani butan yaitu kriteria pemula, madya, dan utama. Alat analisis yang digunakan adalah PLS-SEM. Dimensi keberlanjutan ECO, EGY, LIT, dan ACT berpengaruh langsung positif signifikan terbadap SCF. Pengujian bipotesis mediasi menunjukkan bahwa terdapat mediasi parsial dari ECO dan EGY ke SCF yang konsisten dan bernilai positif. Berdasarkan perbitungan nilai koefisien total-effect, diantara kelima dimensi tersebut, nilai ekologi merupakan yang terbesar dan terkuat. Implikasi kebijakannya, aspek ekologi dianggap penting dan strategis. Oleh karena itu, struktur dan komposisi butan masyarakat perlu dijaga nilai dan produktivitasnya.

Kata kunci: Hutan masyarakat berkelanjutan, efek. langsung-tidak langsung, mediasi-total, PLS-SEM

*Corresponding author: tatan.swk@gmail.com 


\section{INTRODUCTION}

Developing and maintaining sustainable forest is a way of supporting sustainable development. Sustainable development pillar was based on three aspects, namely economic, social, and ecology. As pointed out at the 2015 World Summit, those aspects are inter-linked to one another, and also have an important role in promoting sustainable development (G-Assembly, 2005). The relation between those three aspects is not only mutually exclusive but also mutually reinforcing. In the context of the sustainability of the community forest in this case private-forest, the economy-social-ecology aspects have a causal relationship. From the technical point of view, the community of sustainable forest could be articulated beyond those three aspects. Some studies had addressed five aspects or dimension of sustainability: (1) economic; (2) social and culture; (3) ecology; (4) legal and institution; and (5) accessibility and technology (Apipoonyanon et al., 2020; Baral et al., 2018; Ekanayake et al., 2020; Sukwika et al., 2016; Sukwika et al., 2020; Tadesse \& Teketay, 2020).

In the sustainable development scheme, the relation among the three aspects will form equitable, viable, and bearable relationship, as resulted from the economic-social, economic-ecology, and social-ecology relations (Munasinghe, 1992), respectively (Figure 1). Meanwhile, the role of the other two aspects (legal and institution as well as accessibility and technology) acted as a bridge to identify the factors that could not be reflected by the three aspects. This study aims to analyse the impact of the five aspects and their relations (direct and

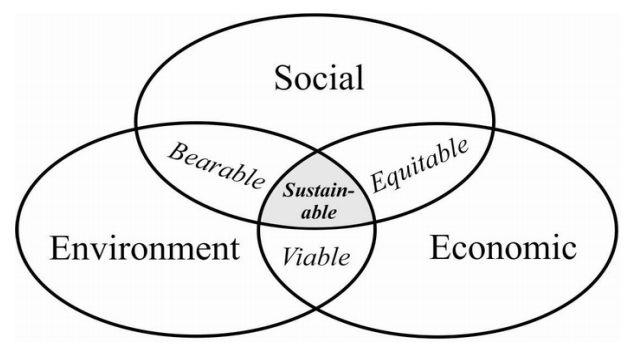

Figure 1. Three pillars and their relationships in the sustainable development scheme indirect) on sustainability of community forest. For that purposes, path analysis approach, a further development of multiple regression was used in this study to estimate the magnitude and significance of causal relationship among variables (MacKinnon et al., 2012; Maslowsky et al., 2015; Sarstedt et al., 2017; Thoemmes et al., 2010; Turnes \& Ernst, 2015; Ullman \& Bentler, 2013; Vinzi et al., 2010).

Sustainability of community forests in Bogor, indirectly, is a result of connectivity among the sustainability dimension (Musyoki et al., 2016; Sukwika et al., 2016; Sukwika et al., 2020). It explained that mediation variable $\mathrm{M}$ is one that determines the effect between the independent variable and the dependent variable (Kenny \& Judd, 2014; MacKinnon et al., 2012; Maslowsky et al., 2015; Sarstedt et al., 2017; Turnes \& Ernst, 2015; Vinzi et al., 2010) (Figure 2). There was a more-intensive utilization of moderation and mediation in the statistical analysis stateof-the-art (Paul, 2013). Using moderation concept, for instance, existing in the context of a theory, it was stated that poverty is one of the determinant factors of environmental degradation, as well as negative-exploitative and inefficient-behaviour in natural resources management. On the contrary, degradation of environment support system could be a determinant factor of poverty (Kusmana \& Sukwika, 2018; Musyoki et al., 2016; Sukwika et al., 2016; Sukwika et al., 2020; Tadesse \& Teketay, 2020). The connectivity is as follow: [X] Farmers' purchasing power (Economic) $\rightarrow[\mathrm{M}]$ Consumption and Production Pattern (Ecology) $\rightarrow[\mathrm{Y}]$ Poverty of farmers' household (Social).

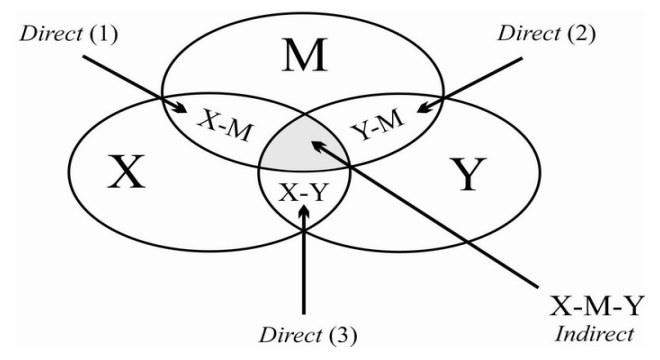

Figure 2. Mediation model 
Farmers' purchasing power affects farmers' behaviour in managing the forest and other resources, through the mode they carried out consumption and production. The implication on farmers' welfare will be there once using an efficient, as well as a more-wise (not exploitative) mode of consumption and product, and vice-versa. Figure 2 shows that relation between economic $(\mathrm{X})$ and social $(\mathrm{Y})$ was mediated by ecology (M) so that X-M-Y is a condition of sustainability of community forest (SCF)(Dawson, 2014; Holland et al., 2016; Memon et al., 2018; Nitzl et al., 2016; Paul, 2013). This study aims to determine variables of sustainability dimensions that have direct positive effect on the sustainability of the community forests $(\mathrm{SCF})$; identify variables that affect SCF; and identify variables of sustainability dimensions that have a dominant effect on SCF.

\section{MATERIAL AND METHOD}

\section{A. Research Location}

The research was conducted in community forest areas that have forest farmers' group assisted by BP3K (Agricultural, Fisheries and Forestry Extension Centre) in Bogor Regency.

\section{B. Methods}

This study employed 70 samples of forest farmers' group selected purposively based on certain criteria $\mathrm{i}$ e. beginner, advanced and intermediate based on BKP5K (Food Security Agency and Implementing Agricultural, Fisheries and Forestry Extension) data, there are 312 forest farmer groups clustered based on four levels of ability. The distribution includes, 107 beginner groups, 160 advanced groups, 42 middle groups, and 3 main groups. Furthermore, 70 respondents $(22 \%)$ of the 312 groups were selected proportionally according to group representation with the details of respondents from the beginner group of 24 farmer groups (107×22\%), advanced, 36 farmer groups $(160 \times 22 \%)$, intermediate 9 farmer groups $(42 \times 22 \%)$, and main 1 person
$(3 \times 22 \%)$. The sample of 70 respondents of forest farmers' group was selected purposively, which uses $90 \%$ confidence level by using Taro Yamane method, (Ali \& Bhaskar, 2016; Singh \& Masuku, 2014; Yamane, 1967). A recommended sample size criteria for PLSSEM (partial least squares structural equation modelling) utilization is somewhere between 30 to 100 (Sarstedt et al., 2017; Ullman \& Bentler, 2013; Ursachi et al., 2015).

Partial least square is a multivariate statistical technique that can handle many response variables as well as explanatory variables at once. This analysis is a good alternative for multiple regression analysis methods and principal component regression, because this method is more robust. Robust means that the model parameters do not change much when a new sample is taken from the total population. Partial Least Square is also a predictive technique that can handle many independent variables, even if there is multicollinearity between these variables (Costa et al., 2012; Ghozali \& Latan, 2015b; Hair et al., 2012, 2013).

\section{Assumption and Hypothesis}

Path analysis is based on the following assumptions: (1) relation among variables is linear and additive; and (2) considers the model which contains only one-direction causal loop (recursive). Parameter estimation method in PLS is using ordinary least square (OLS), which was carried out to each equation, partially. The estimation covers: (1) weight estimate to determine the score of latent variables; (2) path estimate of the relationships among latent variables and estimation loading between latent variables and their indicators; and (3) mean and intercept for indicators and latent variables (Cham et al., 2012; Ghozali \& Latan, 2015b; Hair et al., 2014; Sarstedt et al., 2017; Ullman \& Bentler, 2013; Vinzi et al., 2010). The calculation process is carried out iteratively, and iteration will be terminated once the convergent condition is attained. The model specification is identified based on theories and relevant concepts. 
The goodness of fit (GoF) model is measured by using $\mathrm{R}$-square of latent dependent variable with the same interpretation of the regression; Q-square predictive relevant for a structural model is used-, to measure the goodness of observation value resulted by the model and estimation parameter. Q-square value of $>0$ shows that the model has predictive relevance. Convergent validity test is to see the correlation between the score of reflexive indicator and a score of latent variables. For this, loading score of $0.5-0.6$ is considered sufficient in the case of 3-7 indicators for each construct. Discriminant validity is carried out to compare the value of the square root of average variance extracted (AVE) for each construct, with a value of correlation among other constructs in the model. If the construct's AVE is bigger than other construct's correlation, then the model's discriminant validity is good. It is recommended that the value of measurement should be above 0.50. Group of indicators that measure particular should have composite reliability score of 0.7 , even though it is not an absolute standard (Ghozali \& Latan, 2015b; Hair et al., 2014; Valentini \& Damasio, 2016).

Hypothesis testing $(B, \gamma$, and $\lambda)$ is carried out using a method of bootstrap resampling which was developed by Geisser and Stone in Muller (2013). Statistical testing that has been used is t-statistic or t-test, with the hypothesis formula as follows.

- Statistic hypothesis for an outer model for the feasibility of indicator as a latent variable measurement instrument is $\mathrm{H}_{0}: \lambda=0$ vs $\mathrm{H}_{1}$ : $\lambda \mathrm{i} \neq 0$.

- Statistic hypothesis for the inner model for the latent effect of the exogenous variable to the endogenous variable is $\mathrm{H}_{0}$ : $\gamma \mathrm{i}=0$ vs $\mathrm{H}_{1}$ : $\gamma \mathrm{i} \neq 0$.

- Statistic hypothesis for the inner model for the latent effect of the endogenous variable to the endogenous variable is $\mathrm{H}_{0}: \mathrm{Bi}=0$ or $\mathrm{H}_{1}: \beta \mathrm{i} \neq 0$.

Application of resampling method provides the possibility of distribution-free data, which is not needed to fulfil normality assumption and big (minimum of 30) sample size. The testing held by t-test, if it obtained p-value $=0.05$ (alpha 5\%), it could be concluded as significant, and vice versa. Reliance degree in this research is $95 \%$, which $\alpha=0.05$, respondent $n=70$. and independent variable $k=1$. With formula to find t table $=(\alpha / 2 ; n-k-1)$, so it give result for value of $\mathrm{t}$ table of $\alpha / 2=0025 ; \mathrm{n}-\mathrm{k}-1=69$. Refer to "value distribution guide $\mathrm{t}$ table", it gives result for $t$ table value of 1.99 .

The background of consideration in t-test testing is: $\mathrm{H}_{0}$ rejected and $\mathrm{H}_{1}$ accepted if Sig. value $<0.05$ the meaning is there is a significant effect between the independent variables on dependent variable. Otherwise, $\mathrm{H}_{0}$ accepted and $\mathrm{H}_{1}$ rejected if Sig. value > 0.05. Then, mediational hypothesis testing can carry out with two ways, causal step and product of coefficient strategy, refer to Figure 3 (AmirKhali, 2013; Fritz et al., 2012; Karazsia et al., 2013; Kenny \& Judd, 2014; Memon et al., 2018; Turnes \& Ernst, 2015).

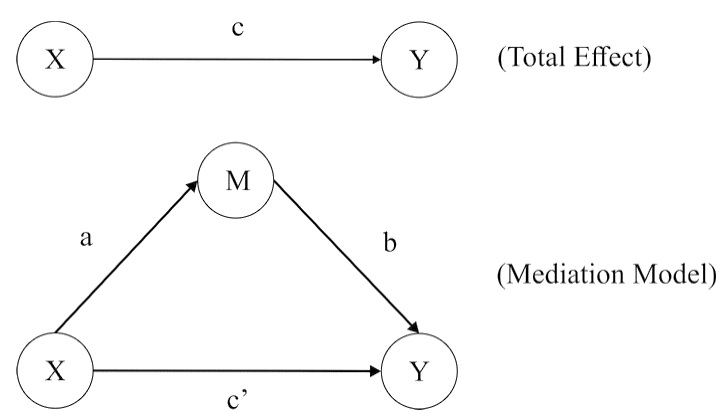

Figure 3. The strategy of the model of the causal steps

The essential point of causal step in mediational hypothesis testing interaction between effect mediator independent variable and mediator effect dependent variable (MacKinnon et al., 2012; Thoemmes et al., 2010). If the coefficient of $c^{\prime}$ is insignificant $\left(c^{\prime}=0\right)$, the perfect or complete mediation condition is consisting. But, if c' coefficient decreases but it remain significant $\left(c^{\prime} \neq 0\right)$, it will be concluded as consist (MacKinnon et al., 2002; Nitzl et al., 2016; Preacher \& Hayes, 2004). Meanwhile, mediational hypothesis testing by using the product of coefficient strategy based on significant indirect effects 
"ab" testing. Significant testing is using the resampling method, bootstrapping (Afanadorac et al., 2013; Carrión et al., 2017; Chernick, 2011; Cheung \& Lau, 2007; Ghozali \& Latan, 2015b). The bootstrapping method developed by Andrew F. Hayes (Preacher \& Hayes, 2008) is considered more effective because there is no normality assumption needed and large sample as is Sobel Test who popularized by Baron and Kenny (1986).

\section{Test of Validity and Reliability}

Validity test validity is a test of the accuracy or accuracy of a measuring instrument in measuring what is being measured. The validity test aims to assess whether a set of measuring instruments correctly measures what should be measured (Ghozali \& Latan, 2015a; Hair et al., 2012, 2013; Hair et al., 2017). Reliability is how far the scale would give consistent result if the instrument used continuously and give the same measurable result. (Ali \& Bhaskar, 2016; Malhotra, 2017; Singh \& Masuku, 2014; Ursachi et al., 2015; Valentini \& Damasio, 2016). In this research, the reliability test for each variable was measured by Cronbach's alpha. There are two reasons for using Cronbach's alpha test (Bryman \& Bell, 2007; Taber, 2016; Ursachi et al., 2015): (1) this method is a most used reliability test method; and (2) by using Cronbach's alpha inconsistent indicator will be detected. Eisingerich and Rubera (2010) stated that the minimum reliability value of Cronbach's Alpha is $0.70(\geq 0.7)$, and it contributes to internal consistency.

Average variants and composite reliability that suggested is more than minimum reliability degree value (Sarstedt et al., 2017; Turnes \& Ernst, 2015; Ullman \& Bentler, 2013). Reliability degree values of Cronbach's Alpha are less reliable $(0-0.20)$, quite reliable $(>0.20-0.40)$, adequate reliable $(>0.40-0.60)$, reliable $(>0.60-$ $0.80)$, and well reliable $(>0.80-1,00)$ (Ghozali \& Latan, 2015b; Hair et al., 2016; Taber, 2016; Ullman \& Bentler, 2013; Vinzi et al., 2010). Another reliability testing can be carried out by considering composite reliability (CR) value from an indicator block that measures the construct (Ursachi et al., 2015; Valentini \& Damasio, 2016). CR result will show satisfied value if more than 0.7 .

There were six variables with 24 indicators tested in this research's validity and reliability tests. Those are economic variable (6 indicators namely, informal labour, wood productivity, farmers' income, bargaining position of middleman, market price incentives for community timber, and sawn wood market), social and culture variable (4 indicators namely, increased value-added of wood, employment rate, forest farmer's household poverty, and farming socialization), Ecology variable (3 indicators namely, land-use to built-up land, conservation of degraded land, and land-use efficiency) and Legal and Institutional variable (4 indicators namely, microfinance institutions, the number of forestry extension agents, agriculture and forestry extension program, and government extension organization), Accessibility and Technology variable (4 indicators namely, access road to the public service centre, access to timber market information, post harvest wood processing, and logging method) and Sustainability of Community Forests variable (3 indicators namely, regional economic growth, regional poverty, and welfare of the forest community).

\section{RESULT AND DISCUSSION}

As explained above, the measurement evaluation model uses 24 indicators. These indicators are obtained from literature studies such as research journals, forest regulations, Centre for International Forestry Research (CIFOR), sustainable production forest management (PHPL), central statistical agency (BPS), and other standard guidelines and also based on field observations in accordance with the principles of sustainable development.

\section{A. Model Measurement Evaluation (Model Outer)}

Determination of indicators is based on the participation of forest farmer groups 
in maintaining sustainable economic, social, environment, and institutions. The criteria for determining the indicators must meet the criteria of (a) sensitive, which has a high level of sensitivity when used to measure, that could minimize the number of indicators needed, (b) specific, which has clear coverage to prevent overlapping, (c) relevant, which is related to the object to be measured.

Determination of the economic indicators to assess forest management activities by forest farmer groups such as family income sources, farmers' ability to provide for family needs, farming activities and others. The social and cultural factors considered include welfare, poverty conditions, and land ownership. Ecological factors focus on indicators of environmental concern, land conversion, and productive land use. Institutional and legal factors include access to information, the role of extension workers, forest farmer groups. The accessibility and technology factors were measured through indicators of the use of agricultural technology, market access, and post-harvest processing.
An indicator is a variable that is used to measure a change, either directly or indirectly, to a condition. Something deserves to be used as an indicator when it meets the following criteria: (1) valid, which can be used to measure the object to be assessed. (2) reliable, i.e. can be trusted. That is, being able to show consistent results when repeated measurements are made both now and in the future.

Table 1 shows Cronbach's alpha testing result and CR that have small value which were [ACT] Accessibility and Technology dimension value 0.895 and [SOC] Social and Culture value 0.910, or both values is more than 0.7 . The validity test result shows that all indicator is valid due to the average variance extracted (AVE) value which is more than 0.5 . Validity test result with Cronbach's alpha shows that all indicator is reliable due to it has alpha value of more than 0.7. To get the Goodness of Fit (GoF) value on PLS-SEM, it shall be formulated by $\sqrt{\mathrm{AVE} * \mathrm{R}^{2}}$ (Tenenhaus et al., 2005; Valentini \& Damasio, 2016). Good results of validity and reliability test shows that construct method is robust (strong) (Cham et al., 2012; Maslowsky

Table 1. Reliability and validation test on the dimensions of community forest sustainability

\begin{tabular}{|c|c|c|c|c|c|}
\hline \multirow[b]{2}{*}{ Variable } & \multicolumn{2}{|c|}{ Reliability } & \multirow{2}{*}{$\begin{array}{c}\text { Validation } \\
\text { Average } \\
\text { Variance } \\
\text { Extracted } \\
\text { (AVE) }\end{array}$} & \multirow[b]{2}{*}{ GoF } & \multirow[b]{2}{*}{ Desc. } \\
\hline & $\begin{array}{l}\text { Cronbach's } \\
\text { Alpha }\end{array}$ & $\begin{array}{c}\text { Composite } \\
\text { Reliability } \\
\text { (CR) }\end{array}$ & & & \\
\hline [ECO] Economic & 0.960 & 0.968 & 0.833 & NA & Good (fit) \\
\hline [SOC] Social \& Culture & 0.910 & 0.937 & 0.789 & 0.806 & Good (fit) \\
\hline [EGY] Ecology & 0.933 & 0.957 & 0.882 & 0.898 & Good (fit) \\
\hline [LIT] Legal \& Institutional & 0.955 & 0.967 & 0.881 & 0.810 & Good (fit) \\
\hline [ACT] Accessibility \& Technology & 0.895 & 0.927 & 0.761 & 0.796 & Good (fit) \\
\hline [SCF] Sustainability of Community Forests & 0.944 & 0.964 & 0.899 & 0.916 & Good (fit) \\
\hline
\end{tabular}

Remarks:

[ECO1] informal labor, [ECO2] wood productivity, [ECO3] farmers' income, [ECO4] bargaining position of middleman, [ECO5] market price incentives for community timber, [ECO6] sawn wood market. [SOC1] increased value-added of wood, [SOC2] employment rate, [SOC3] forest farmer's household poverty, [SOC4] farming socialization. [EGY1] land-use to built-up land, [EGY2] conservation of degraded land, [EGY3] land-use efficiency. [LIT1] microfinance institutions, [LIT2] the number of forestry extension agents, [LIT3] agriculture and forestry extension program, and [LIT4] government extension organization. [ACT1] access road to the public service centre, [ACT2] access to timber market information, [ACT3] postharvest wood processing, [ACT4] logging method. [SCF1] regional economic growth, [SCF2] regional poverty, [SCF3] welfare of the forest community. 
et al., 2015; Ursachi et al., 2015) and hypothesis test can be carried out.

Figure 4 shows Economic (ECO) Constructed variable measured by six) indicators included ECO1, ECO2, ECO3, ECO4, ECO5 and ECO6. Constructed (latent variable) Social and Culture (SOC) measured by four indicators, know as SOC1, SOC2, SOC3, and SOC4. Constructed Ecology (EGY) measured by three indicators: EGY1, EGY2, and EGY3. Constructed legal and institutional (LIT) measured by four indicators, they are LIT1, LIT2, LIT3, and LIT4. Constructed accessibility and technology (ACT) measured by four indicators: ACT1, ACT2, ACT3, and ACT4. Constructed the main target is the sustainability of community forests (SCF) measured by three indicators: SCF1, SCF2, and SCF3. The arrow between the indicator and the latent construction shows that the study uses the correct reflective indicator to measure perception. Object relations are symbolized with an arrow between constructs. Figure 4 shows that the loading factor with the smallest amount is 0.825 (indicator $\mathrm{SOC}_{2}$ ) or more than 0.5. It means that other applicable indicators in this research are valid or fulfilled the convergent validity requirement (Cham et al.,
2012; Dawson, 2014; MacKinnon et al., 2012; Turnes \& Ernst, 2015; Vinzi et al., 2010).

Connectivity Effect Path Across Variable for Forest Community Sustainability. Based on connection testing to the across variables path there is a relation between two variables that are not significant, namely the SOC Variable Effect to EGY. This non-signification indicated by the p-value of 0.254 or exceeds the recommended $\mathrm{p}$-value of 0.05 . Generally, the interpretation of $\mathrm{p}$-value based on the parameter value must be smaller than the threshold value, which is 0.05 . Where, if the value of $\mathrm{p}<0.05$, it is considered that a relation between variables is significant. On the contrary, it is not significant if the value of $\mathrm{p}>0.05$. Table 2 shows that the connectivity relation of variables is significant $(\mathrm{p}$-value $=0)$ ACT to SCF, ECO to EGY, ECO to SOC, and SOC to LIT.

The original sample estimate value is positive, that is 0.908 , which shows that the direction of connectivity between ECO and SCF is positive. The T-statistic value, which is not significant, is found in the relation between SOC and EGY variables 1,143 . The value of the relationship between other variables is significant. The lowest significant t-statistic value is 1.99. Path coefficient validation test for each direct effect

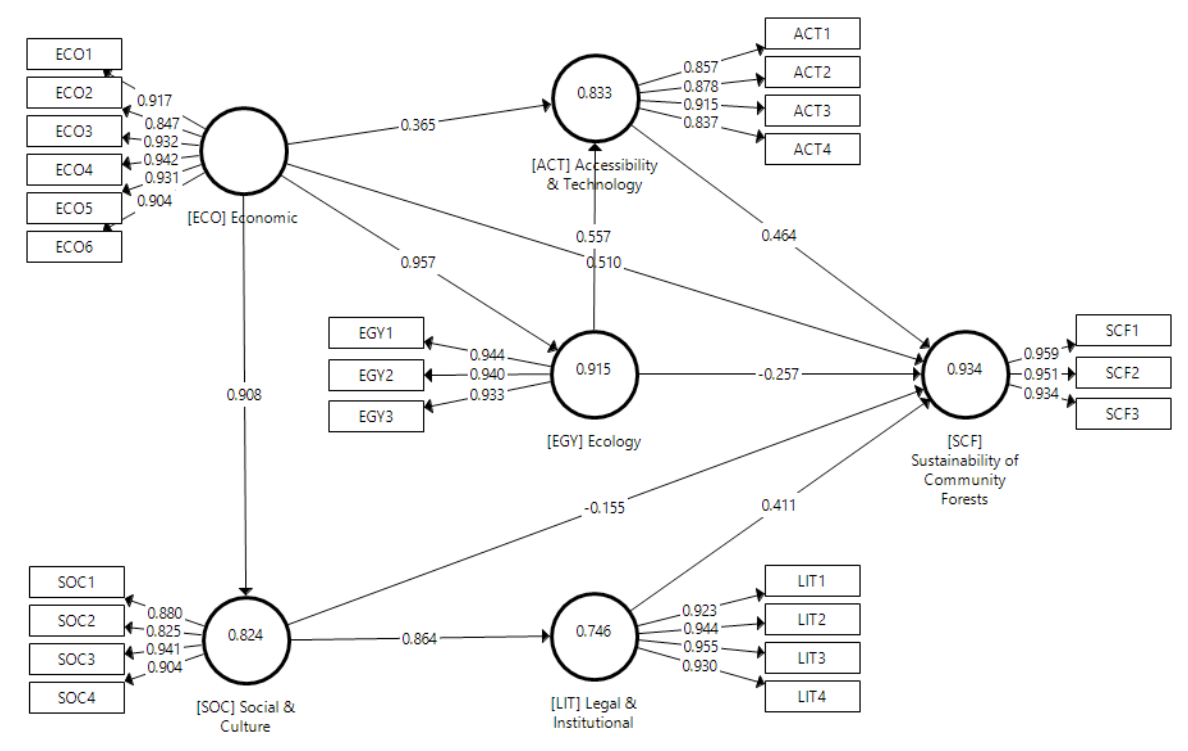

Figure 4. Structural path diagram for the sustainability of community forests, the results of the PLSSEM algorithm 
Table 2. Test the path coefficient: Sample, mean, STDEV, t-statistic, p-values

\begin{tabular}{rclrrrrr}
\hline No. & Variable & $\begin{array}{r}\text { Original } \\
\text { Sample } \\
(\mathbf{O})\end{array}$ & $\begin{array}{r}\text { Sample } \\
\text { Mean } \\
(\mathbf{M})\end{array}$ & $\begin{array}{r}\text { Standard } \\
\text { Error } \\
(\text { STERR) }\end{array}$ & $\begin{array}{r}\text { T Statistics } \\
(\mid \mathbf{O} / \text { STERR } \mid)\end{array}$ & P-values \\
\hline 1. & {$[\mathrm{ACT}]$} & $\rightarrow[\mathrm{SCF}]$ & 0.463 & 0.467 & 0.100 & 4,622 & 0 \\
2. & {$[\mathrm{EGY}]$} & $\rightarrow[\mathrm{ACT}]$ & 0.557 & 0.544 & 0.191 & 2,925 & 0.004 \\
3. & {$[\mathrm{EGY}]$} & $\rightarrow[\mathrm{SCF}]$ & -0.256 & -0.254 & 0.129 & 1,995 & 0.047 \\
4. & {$[\mathrm{ECO}]$} & $\rightarrow[\mathrm{ACT}]$ & 0.365 & 0.377 & 0.179 & 2,036 & 0.042 \\
5. & {$[\mathrm{ECO}]$} & $\rightarrow[\mathrm{EGY}]$ & 0.835 & 0.833 & 0.108 & 7,771 & 0 \\
6. & {$[\mathrm{ECO}]$} & $\rightarrow[\mathrm{SCF}]$ & 0.509 & 0.489 & 0.194 & 2,619 & 0.009 \\
7. & {$[\mathrm{ECO}]$} & $\rightarrow[\mathrm{SOC}]$ & 0.908 & 0.909 & 0.030 & 30.022 & 0 \\
8. & {$[\mathrm{LIT}]$} & $\rightarrow[\mathrm{SCF}]$ & 0.411 & 0.428 & 0.170 & 2,412 & 0.016 \\
9. & {$[\mathrm{SOC}]$} & $\rightarrow[\mathrm{EGY}]$ & 0.133 & 0.137 & 0.117 & 1,143 & 0.254 \\
10. & {$[\mathrm{SOC}]$} & $\rightarrow[\mathrm{SCF}]$ & -0.154 & -0.158 & 0.059 & 2,614 & 0.009 \\
11. & {$[\mathrm{SOC}]$} & $\rightarrow[\mathrm{LIT}]$ & 0.864 & 0.865 & 0.043 & 20.291 & 0 \\
\hline
\end{tabular}

path is the same as for the regression, using the $\mathrm{t}$ value of the $\mathrm{t}$-test, testing the variable regression coefficient is partially standardized (Ghozali \& Latan, 2015b; Hair et al., 2014).

Based on trimming theory, non-significant pathways discarded, in this research, the SOC variable to EGY, so that a model that is supported (confirmed) by empirical data is obtained. Discriminant validity reflexive indicators can be seen in the cross-loading between the indicator and its construct (Sarstedt et al., 2017; Ullman \& Bentler, 2013; Vinzi et al., 2010). Table 2 shows the correlation construct with its indicator (bold) is higher than the correlation indicator innovation with other constructs. This shows that the latent construct predicts the indicators in each block itself better than the indicators in other blocks. Overall, the construct has high discriminant validity. Based on the weight value, most indicators show less than 0.1 ; then it could be concluded that all indicators on each latent contract can still be used in modelling.

\section{B. Structural Model Testing (Inner Model)}

Coefficient of Determination. Structural model testing used to evaluate the estimation parameter coefficient path value and its significant degree. The first test can be done by calculating R-Square Value which is a goodness- fit model and next test is done by assessing the construct significant effect and consider the coefficient parameter value and significant $t$ statistic value (Maslowsky et al., 2015; Sarstedt et al., 2017; Turnes \& Ernst, 2015; Vinzi et al., 2010).

The coefficient of determination with $r^{2}$ symbol is the proportion of variability in a calculated data based on a statistical model. The following definition states that $r^{2}$ is the ratio of the variability of values made by the model to the variability of the original data values. In general, $\mathrm{r}^{2}$ is used as information about the suitability of a model. In regression, $\mathrm{r}^{2}$ is a measurement of how well the regression line approach the original data values created by the model. If $r^{2}$ is equal to 1 , then the number shows the regression line matches the data perfectly (Ghozali \& Latan, 2015b; Hair et al., 2014).

Another interpretation is that $\mathrm{r}^{2}$ is defined as the proportion of variation of responses explained by the regressor (independent variable/X) in the model. Thus, if $\mathrm{r}^{2}=1$ will mean that the corresponding model explains all the variability in the $\mathrm{Y}$ variable. If $\mathrm{r}^{2}=0$ will mean that there is no relationship between the regressor $(\mathrm{X})$ and the $\mathrm{Y}$ variable. In the case for example if $\mathrm{r}^{2}=0.833$ it has the meaning that 
$83.30 \%$ of the variation of the endogenous variable ACT (dependent variable/response) can be explained by the variable $\mathrm{X}$ (independent variable/explanatory); while the remaining 16.70 is influenced by unknown variables or inherent variability. Table 3 shows that the endogenous variable LIT has a coefficient of determination value, $r^{2}=0.746$. There was a change in the coefficient of determination after trimming, but it was exceedingly small. Based on the coefficient of total determination (trimming results), it was found that the model can explain the information contained in the data, amounting to $80.9 \%$. This figure is exceptionally high, so it is worth further interpretation. After trimming the SOC variable path to the EGY variable p-value above 0.05 , on the other hand, the exogenous and endogenous variable values of $\mathrm{p}$ are below $0.05(\mathrm{p}<0.05)$ or significant category, where the largest value is 0.045 , i.e. there is a variable path EGY to SCF.

In the structural path analysis, the path scheme discussed the basic path connecting the origin of the dimension variable to the SCF variable as the destination path directly or through other variables first. In analysing the structural path, the path identified have direct effects, indirect effects and total effects (MacKinnon et al., 2012; Maslowsky et al., 2015; Turnes \& Ernst, 2015).

In general, the ECO dimension variable directly reflects positively to SOC, EGY, ACT, and SCF. If there is an improvement in the sustainability of the ECO dimension, the conditions in the dimensions of SOC, EGY, ACT and SCF will also improve, and vice versa.
The estimation results shows that the Variable Effect dimension of ECO to SOC has a path coefficient of 0.908 or the magnitude of the ECO effect on SOC of $90.80 \%$. Where the effect is significant at the value of $t=28,501$ $(>\mathrm{t}$ table $=1.99)$. Variable ECO to EGY has a significant effect of 0.957 or $95.70 \%$. Likewise, with the ECO variable for ACT and SCF each of 0.365 or $36.50 \%$, and 0.510 or $51 \%$. Overall, calculation results show a probability value $<0.05$, there is enough data to reject $\mathrm{H} 0$ and accept H1. That is, there is a linear relationship between the ECO variable with SOC, EGY, and ACT.

Figure 4 shows the measurement results of the effects of each variable on the sustainability dimension to each of the lever indicators. The overall calculation results show a significantgood probability value $(<0.05)$ and $t$ statistics $(>t$ table $=1.99)$. All sustainability dimension variables show a positive effect on the lever indicator. It is indicated by the positive estimation value. The lowest estimation value is the effect of the SOC dimension variable of the labour absorption rate [SOC2], the path coefficient of 0.825 or $82.50 \%$.

Indicators become a lever factor in the ECO dimension are not attracting workers in the informal forestry sector from farming families (ECO1), low monthly farmer income (ECO3), low bargaining power of farmers towards forest product (ECO4, ECO6), and low productivity of timber farmer (ECO2). Economic dimension (ECO) levers are related to Social \& Culture (SOC) issues such as poverty (SOC3). Here it can be explained that the direct effect received

Table 3. The coefficient of determination $\left(\mathrm{r}^{2}\right)$ before (original) and after trimming

\begin{tabular}{lcccc}
\hline \multirow{2}{*}{ Endogenous variable $\left(\mathbf{P}_{\mathrm{ep}}\right)$} & \multicolumn{2}{c}{ R Square } & change & Total \\
\cline { 2 - 3 } & original & trimming & $\mathbf{r}^{2}$ & $\mathbf{r}^{\mathbf{2}}$ \\
\hline Accessibility \& Technology [ACT] & 0.833 & 0.833 & fixed & 0.694 \\
Ecology [EGY] & 0.918 & 0.915 & down & 0.837 \\
Sustainability of Community Forests [SCF] & 0.933 & 0.934 & up & 0.872 \\
Legal \& Institutional [LIT] & 0.746 & 0.746 & fixed & 0.557 \\
Social \& Culture [SOC] & 0.824 & 0.824 & fixed & 0.679 \\
& & & $R_{m}^{2}=1-P_{e 1}^{2} P_{e 2}^{2} \ldots \mathrm{P}_{\mathrm{p}}^{2}=0.809$ \\
\hline
\end{tabular}


Table 4. Direct effect, indirect effect, and the total effect

\begin{tabular}{lccrr}
\hline \multirow{2}{*}{ Variable } & \multirow{2}{*}{ Direct effect } & \multirow{2}{*}{ Indirect effect } & \multicolumn{2}{c}{ Total effect } \\
\cline { 4 - 5 } Ecology & $0.334^{* *}$ & 0.561 & 0.895 & Average \\
Social and Culture & 0.047 & 0.778 & 0.825 & 0.895 \\
Economic & $0.378^{* *}$ & 0.477 & 0.855 & 0.862 \\
Legal and Institutional & $0.582^{* *}$ & - & 0.582 & 0.597 \\
Accessibility and Technology & $0.408^{* *}$ & - & 0.408 & 0.393 \\
\hline
\end{tabular}

Remarks : ${ }^{* *}$ significant at $\alpha$ level $=0.05$

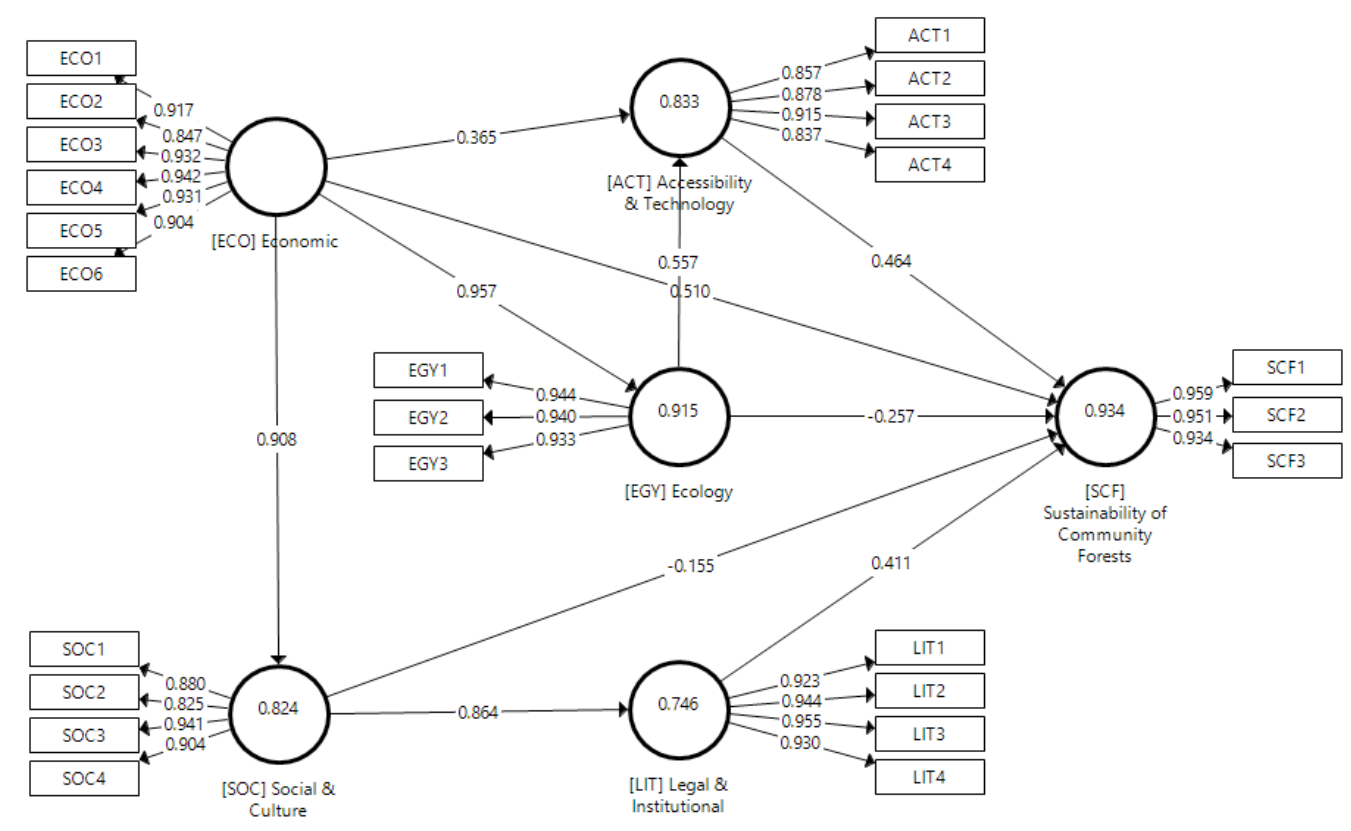

Figure 5. Structural path diagram for the sustainability of community forests, the results of the PLS-

SEM algorithm

by the poverty indicator from each increase of indicators in the ECO dimension is 0.941. That is, there is a significant direct influence on indicators in the economic dimension such as high informal labour, wood productivity, farmers' income, and bargaining position of middleman, all of which affect poverty indicators in the social dimension. According to Sukwika et al. (2018), easy market access and the added value of timber can suppress the bargaining power of the middleman hence reducing poverty. The direct effect generated through the ECO to SOC which has a direct effect of is 0.908 (Figure 5).

Income (ECO3) is related to the availability of employment, especially for informal workers
(ECO1), business conditions (ECO2, ECO5), and other economic factors. Provision of employment opportunities is needed by all parties so that the community has a better income to meet the family's living needs. Thus, as conditions improve in the economic dimension, it can have a positive effect on reducing the problem of poverty (SOC3) and to encourage the participation of farmers (SOC1) in achieving prosperity through community forest activities. Improving economic conditions (ECO) have a positive effect on ecology (EGY), especially the behaviour of farmers in using land more productively both as cultivated land (EGY2) and for their landuse efficiency (EGY3) in a direction that can 
get economic values. Economic conditions [ECO] positively affect farmers' efforts to increase the added-value of timber through postharvest timber processing (ACT3) and study of standard logging techniques (ACT4) and are supported by encouragement to gain access to timber market information (ACT2).

To find out whether there is perfect or partial mediation can be shown if the coefficient $\mathrm{c}$ is statistically significant. Complete mediation occurs when independent variables do not influence the dependent when the mediator is controlled (Fritz et al., 2012; Hayes \& Rockwood, 2016; Karazsia et al., 2013; Kenny \& Judd, 2014; Nitzl et al., 2016). If the coefficient c is statistically significant, and there is also a significant mediation, then it is called partial mediation. The causal step strategy itself has a weakness to detect mediation; the requirements must comply where the relationship X to Y must be significant and become insignificant when there is perfect mediation (direct effect $=0$ ), whereas there are many cases where mediation significant but the relationship $\mathrm{X}$ to $\mathrm{Y}$ is not significant (MacKinnon et al., 2012; Sarstedt et al., 2017; Thoemmes et al., 2010; Turnes \& Ernst, 2015; Ullman \& Bentler, 2013).

Besides, it is also necessary to see whether the mediation model is consistent or inconsistent. An inconsistent model is a model, where there is at least one mediating effect that has a different sign from another mediation effect or a direct effect. In other words, if c (direct effect) is the opposite of $a b$ (indirect effect), the mediator will act as a suppressor variable. This inconsistent model is the opposite of a consistent model in which direct and indirect effects have the same sign. It shows that there is an inconsistent mediation effect (suppression), but the first criterion (the $\mathrm{X}$ to $\mathrm{Y}$ relationship is not significant). For example, $\mathrm{X}$ (predictor), $\mathrm{M}$ (mediator) and $\mathrm{Y}$ (criterion). In the mediation model, the direct effect of the predictor on the criterion is negative, and the indirect effect of the predictor on the error mediated by the mediator is positive (Hayes \& Scharkow, 2013; Turnes \& Ernst, 2015; Yzerbyt et al., 2018).
Variable of the ECO (predictor) dimension has a direct relationship to SCF (criterion) will have a positive path coefficient of 0.378 or $38 \%$ with a probability value of $<0.05$, then there is enough data to reject $\mathrm{H} 0$ and accept H1. If using the mediational hypothesis test approach with casual steps technique, then to calculate the direct effect the following formula is used, see Figure 5: (1) variable effect independent / predictor of the mediator $(\mathrm{X} \rightarrow \mathrm{M})$ is a $=\mathrm{ECO}$ $\mathrm{ACT}+(\mathrm{ECO} \mathrm{EGY} * \mathrm{EGY} \mathrm{ACT})+(\mathrm{ECO}$ $\mathrm{SOC} *$ SOC LIT $)=0.365+(0.957 \times 0.557)$ $+(0.863 \times 0.451)=1,287 ;(2)$ variable effect mediator on dependent/criterion $(\mathrm{M} \rightarrow \mathrm{Y})$ is $\mathrm{b}$ $=\mathrm{ACT}$ SCF + EGY SCF + LIT SCF $=0.448$ $+(-0.292)+0.451=0.607$; (3) variable effect independent/predictor of dependent/criterion $(\mathrm{X} \rightarrow \mathrm{Y})$ is $\mathrm{c}^{\prime}=\mathrm{ECO} \mathrm{SCF}=0.378$. Indirect effect ECO to SCF in this path analysis has 4 (four) paths, they are:

(1) Indirect effect variable dimension ECO (predictor) $(36.5 \%)$ to SCF (criterion) is ACT (mediator) with track coefficient 0.448 . It means increasing of SCF have to be done by increasing economic and followed by an effort to make easier ACT to forest farmers (indirect effect $=44.8 \%$ ).

(2) Indirect effect of ECO to SCF through EGY mediation which has path coefficient value -0.292 . It explains that the acceleration of ECO is by one per cent, then the impact on SCF decreases by $29.2 \%$, and vice versa.

(3) Indirect effect of ECO to SCF (45.1\%) through 2 serial mediator SOC (90.7\%) then LIT $(86.3 \%)$.

(4) Indirect effect of ECO to SCF (44.8\%) through 2 serial mediator is EGY (95.7\%) then ACT (75.7\%).

The total effect captures the direct effect along the path and the indirect effect path of the circuit associated with the path. The total effect (TE) captures the direct effect along the path and the indirect effect path of the circuit associated with the path.(Ghozali \& Latan, 2015b; Hair et al., 2014; Hayes \& Scharkow, 2013; Kenny \& Judd, 2014; MacKinnon et al., 2012; Turnes \& Ernst, 2015). The total ECO effect on SCF is 
0.855 , it means that each increase of the score from the economic dimension by $100 \%$ will increase the SCF score by $85.5 \%$. Value of $\mathrm{R}^{2}$ 0.849 means the number of variants can be explained by the economic dimension of the SCF variation is equal to $84.9 \%$ or equal with $37,1[=\sqrt{ }(1-0.849)]$ explained by the other variables outside the model and error. The total effect value of the ECO dimensions on SCF is obtained by calculating as follows: TE $=$ Path 1 $(\mathrm{ECO} \mathrm{SCF})+$ Path $2(\mathrm{ECO} \mathrm{ACT} *$ ACT SCF $)$ + Path 3 (ECO EGY * EGY SCF) + Path 4 $($ ECO SOC $*$ SOC LIT $*$ LIT SCF $)+$ Path 5 $($ ECO EGY $*$ EGY ACT $*$ ACT SCF $)=0.378$ $+(0.365 \times 0.448)+(0.957 \times-0.292)+(0.907$ $\times 0.863 \times 0.451)+(0.957 \times 0.557 \times 0.448)=$ $0.378+(0.164)+(-0.279)+(0.353)+(0.239)$ $=0.855$.

The result of the direct effect of the mediation model of predictor $\mathrm{X}$ to the criterion $\mathrm{Y}\left(\mathrm{c}^{\prime}\right)$ is significant where the probability value is $0.021<0.05$, and there is a significant indirect mediator $\mathrm{M}$ effect, it can be interpreted as mediation that occurs is partial mediation (Kenny, 2008; Kenny \& Judd, 2014). The mediation effect in the model and the coefficient c'significant, which means there is an effect and when viewed from the value of the direct effect (coefficient c') $\mathrm{X}$ of $\mathrm{Y}$ is 0.51 (positive) or not opposed with indirect effect (coefficient $a b$ ) is 1.002 (positive), it can be said that the mediation model in this study is consistent and directly proportional. Than, it is decided to reject $\mathrm{H}_{0}$ and accept $\mathrm{H}_{1}$, meaning there is a significant effect between the independent variables on the dependent variable.

\section{Economic Dimension Modelling}

The Economic dimension model is formed based on the results of the analysis of valid indicators used in the measurement and variable-latent models that significantly reflect the structural model (Cham et al., 2012; Ursachi et al., 2015; Yzerbyt et al., 2018). From the analysis results obtained an evaluation (validation) from the measurement model that the 24 valid indicators in measurement for each latent construct are shown by loading values for all indicators greater than 0.7 so that all indicators can be used in forming the SCF model.

Based on Figure 6, in this study the SCF model that consists of five structural models and six measurement models are as follows: (1) model of structural for latent variable SOC to LIT $: \eta \mathrm{LIT}=0.864$ $\xi \mathrm{SOC}$; (2) model of structural for latent variable ECO to SOC: $\eta \mathrm{SOC}=0.908$ छECO; (3) model of structural for latent variable ECO to EGY: $\eta \mathrm{EGY}=$ 0.957 छECO; (4) model of structural for latent variable $\mathrm{ECO}$ and $\mathrm{EGY}$ to $\mathrm{ACT}: \eta \mathrm{ACT}=0.365$ $\xi \mathrm{ECO}+0.557 \xi \mathrm{EGY}$; (5) Model of structural for latent variable ACT, ECO, EGY, and LIT to SCF: $\eta \mathrm{SCF}=0.464 \xi \mathrm{ACT}+0.510 \xi \mathrm{ECO}-$ $0.257 \xi \mathrm{EGY}+0.411 \xi \mathrm{LIT}$. Model of Construct Measurement ECO, ACT, EGY, SOC, LIT, and SCF are:

The trend of similar findings in the forestry sector regarding the relationship between dependent and independent variables is evidenced by Tadessa and Teketay (2020)

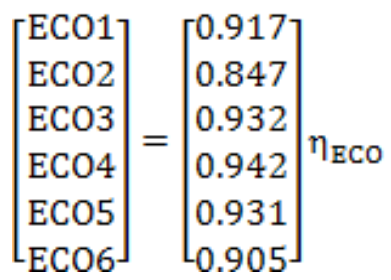

(1) Measurement (ECO)

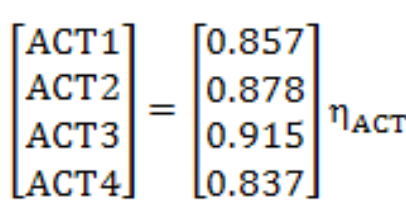

(2) Measurement (ACT)

$\left[\begin{array}{l}E G Y 1 \\ \text { EGY2 } \\ \text { EGY3 }\end{array}\right]=\left[\begin{array}{l}0.944 \\ 0.940 \\ 0.933\end{array}\right] \eta_{E G Y}$

(3) Measurement (EGY)

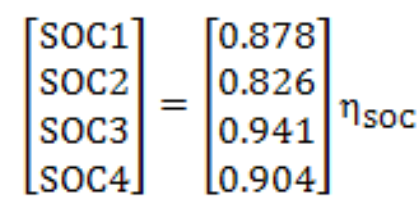

(4) Measurement (SOC) 


$$
\left[\begin{array}{l}
\text { LIT1 } \\
\text { LIT2 } \\
\text { LIT3 } \\
\text { LIT4 }
\end{array}\right]=\left[\begin{array}{l}
0.923 \\
0.944 \\
0.955 \\
0.930
\end{array}\right] \eta_{\text {LIT }}
$$

(5) Measurement (LIT)

$$
\left[\begin{array}{l}
\text { SCF } 1 \\
\text { SCF } 2 \\
\text { SCF } 3
\end{array}\right]=\left[\begin{array}{l}
0.959 \\
0.951 \\
0.933
\end{array}\right] \eta_{\mathrm{SCF}}
$$

(6) Measurement (SCF)

through The multiple linear regression models which revealed that independent variables derived from demographic, socioeconomic, bio-physical, and institutional factors significantly affected the dependent variables, namely the dependencies of local communities on plantation forests. In line with that, Sukwika et al. (2016) also found a direct effect on developing the region's timberbased management and processing through an integrated system that involves community (society) and business, i.e., increased valueadded of wood, information of wood market, and institutional strengthening of forest farmer groups. Subsequently, Van Gossum et al. (2011) and Sukwika et al. (2020) agreed that there are four key actors which are the most dominant having a direct effect in the community-forest action arena, i.e. farmer land-owners, farm labours, lumber-men, and middlemen.

\section{Social Dimension Modelling}

In this study, the SOC dimension model was formed based on the results of the analysis of valid indicators used in the measurement model and the latent variable that significantly reflected the structural model. From the analysis results obtained evaluation results (validation) from the measurement model that the 11 indicators are valid in the measurement of each latent construct indicated by the loading value for all indicators greater than 0.7 , so all indicators can be used in forming the SCF model. Thus, based on Figure 6, in this study, the sustainability of community forests model that can be formed consists of two structural models and three Measurement models as follows (1) model of Structural effect latent variable SOC to LIT is: $\eta \mathrm{LIT}=0.864 \xi \mathrm{SOC} ;(2)$ model of structural latent variable SOC and LIT to SCF is $\eta \mathrm{SCF}$

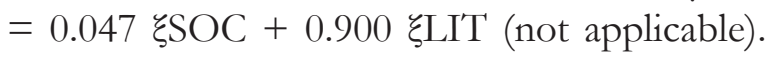
Model of Construct Measurement SOC, LIT, and SCF is:

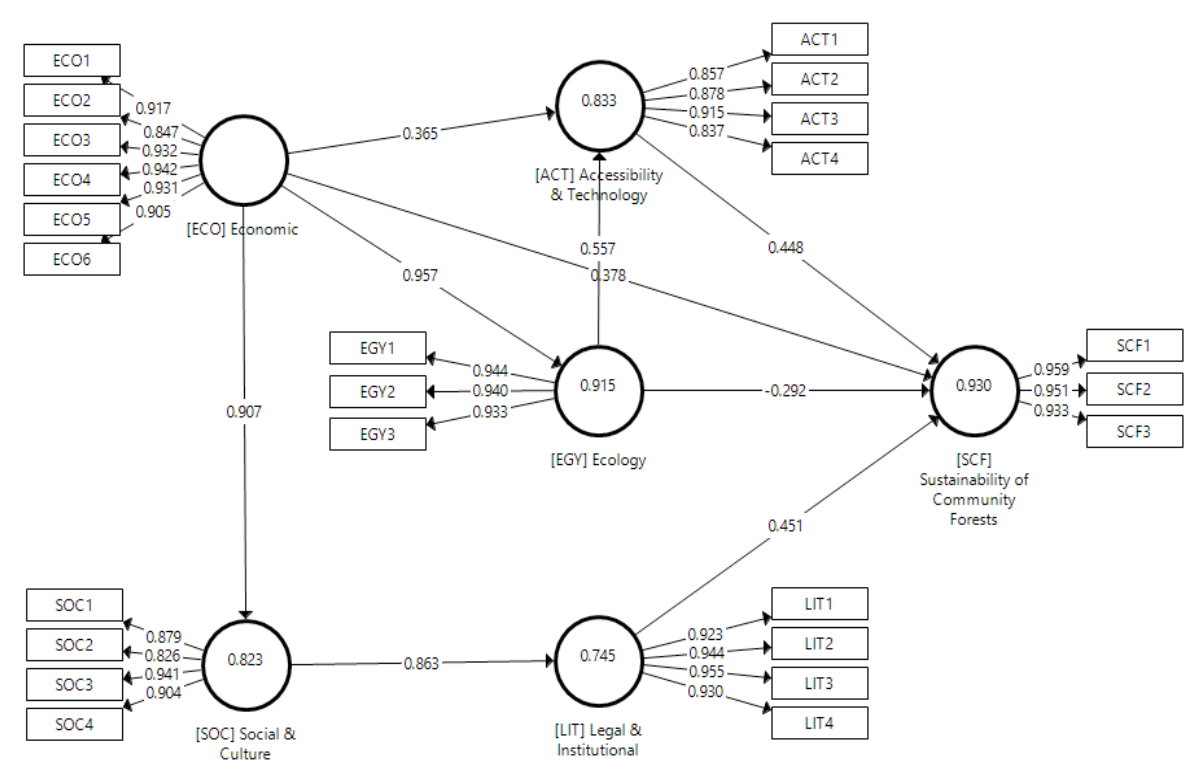

Figure 6. Structural path diagram of economic to the sustainability of community forests, the results of the trimming of PLS-SEM algorithm 


$$
\left[\begin{array}{l}
\text { SOC } 1 \\
\text { SOC2 } \\
\text { SOC } 3 \\
\text { SOC } 4
\end{array}\right]=\left[\begin{array}{l}
0.882 \\
0.824 \\
0.941 \\
0.903
\end{array}\right] \eta_{\mathrm{SOC}}
$$

(1) Measurement (SOC)

$$
\left[\begin{array}{l}
\text { LIT1 } 1 \\
\text { LIT2 } \\
\text { LIT3 } \\
\text { LIT 4 }
\end{array}\right]=\left[\begin{array}{l}
0.923 \\
0.944 \\
0.955 \\
0.930
\end{array}\right] \eta_{\text {LIT }}
$$

(2) Measurement (LIT)

$$
\left[\begin{array}{l}
\mathrm{SCF} 1 \\
\mathrm{SCF} 2 \\
\mathrm{SCF} 3
\end{array}\right]=\left[\begin{array}{l}
0.960 \\
0.952 \\
0.932
\end{array}\right] \eta_{\mathrm{SCF}}
$$

\section{(3) Measurement (SCF)}

The SOC dimension variable directly has a positive effect on SCF with a path coefficient value of 0.047 , with significant level 0.442 or probability value is bigger than 0.05 insignificant cause-effect. Based on Figure 6, the results of causal steps and the product of coefficient indicate not complied. Where, the direct effect model of $\mathrm{X}$ to $\mathrm{Y}$ (c') is not significant in the probability value 0.442 or $\mathrm{p}>0.05$, meanwhile indirect effect $(\mathrm{ab})$ significant is $0.000(\mathrm{p}<0.05)$, means, complete mediation occurs. The results of the consistency test show the value of the direct effect (coefficient c ') $\mathrm{X}$ of $\mathrm{Y}$ is 0.047 (positive) or in the same direction with a positive value of indirect effect (ab) $(0.776=0.864 \mathrm{x}$ $0.900)$, so, that the two mediation models in this study are consistent and have a positive effect. So they can decide to reject $\mathrm{H}_{0}$ and accept $\mathrm{H}_{1}$.

The variable of the SOC (predictor) dimension that has an indirect effect related to the SCF (criterion) is LIT (mediator). The amount of indirect effect is $0.864 \times 0.900=$ 0.778 . In this condition, the policy intervention can be done to improve the performance of the SCF must involve SOC interaction in a participatory manner through an institutional approach and regulatory support.
Although LIT provides an indirect effect of 0.778 , because the LIT position only functions as an intervening or mediating variable, it is difficult to observe and measure. Theoretically, intervening variables affect the relationship between independent variables and dependent variables, but it cannot be observed and measured (Fritz et al., 2012; Hayes, 2013; Hayes \& Rockwood, 2016; Holland et al., 2016; Karazsia et al., 2013; Kenny \& Judd, 2014). For example, the effectiveness of an extension program (LIT3) by extension workers (LIT2) affects the participation of farmers, adding the value of timber (SOC1) to welfare (SCF3). This is the right relation, but the success of farmers' participation adds to the value of timber because of a communication in the extension, so communication in the extension cannot be a specific conclusion for the successful participation of farmers adding value to the timber. But there is still a role for other reflective indicators from the LIT variable. SOC-SCF total effect. Total effect of SOC on SCF is 0.825 , this value is obtained by calculating: TE $=$ Path $1($ SOC SCF $)+$ Path 2 (SOC LIT $*$ LIT $\mathrm{SCF})=0.047+(0.864 \times 0.900)=0.047+0.778$ $=0.825$.

Generally, the findings by Sukwika et al. (2016) and Tadesse and Teketay (2020) suggested that the various independent variables that significantly affected the dependencies of local farmers on community forests also affected their levels of participation in forest management's sustainability activities. Regarding institutions, Sukwika et al. (2018) found the impact of policy strategies on indicators of increasing the proportion of forestry extension personnel and increasing the quality of forestry extension program activities to the sustainability of forest management. Forest plays an important role as incentives to community participation in forest management. Musyoki et al. (2016) revealed that the level of participation of members of community forest associations in participatory forest management activities was positively and significantly influenced by the level of perceived participatory forest management benefits. 


\section{E. Ecology Dimension Modelling}

In this study, the EGY dimension model was formed based on the results of the analysis of valid indicators used in the measurement and variable-latent variable models that significantly reflected the structural model. From the analysis results obtained evaluation results (validation) from the measurement model that the 10 valid indicators in the measurement of each latent construct which is indicated by the loading value for all indicators greater than 0.7 , so that all indicators can be used in forming the SCF model. Thus, based on Figure 7 in the SFC model that can be formed consists of two structural models and three measurement models as follows: (1) model of structural for latent variable EGY to ACT: $\eta$ ACT $=0.907$ छEGY; (2) model of structural for latent variable EGY and ACT to SCF: $\eta$ SCF $=0.334 \xi \mathrm{EGY}+$

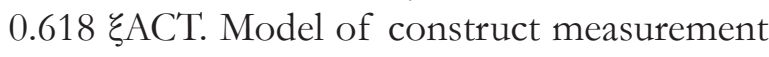
EGY, [ACT, and SCF is:

\section{$\left[\begin{array}{l}\text { ACT } 1 \\ \text { ACT } 2 \\ \text { ACT } 3 \\ \text { ACT } 4\end{array}\right]=\left[\begin{array}{l}0.858 \\ 0.879 \\ 0.915 \\ 0.835\end{array}\right] \eta_{\text {ACT }}$}

(1) Measurement (ACT)

$$
\left[\begin{array}{l}
E G Y 1 \\
E G Y 2 \\
E G Y 3
\end{array}\right]=\left[\begin{array}{l}
0.959 \\
0.950 \\
0.934
\end{array}\right] \eta_{\mathrm{EGY}}
$$

(2) Measurement (EGY)

$$
\left[\begin{array}{l}
\mathrm{SCF} 1 \\
\mathrm{SCF} 2 \\
\mathrm{SCF} 3
\end{array}\right]=\left[\begin{array}{l}
0.943 \\
0.940 \\
0.933
\end{array}\right] \eta_{\mathrm{SCF}}
$$

(3) Measurement (SCF)

Based on Figure 7 result of causal steps and the product of coefficient is completed. Where the direct effect model from $\mathrm{X}$ to $\mathrm{Y}\left(\mathrm{c}^{\prime}\right)$ and indirect effect $(\mathrm{ab})$ significant is $0.000(<0.05)$, it means, the mediation that occurred is partial mediation. The result of consistency test shows that direct effect value (coefficient c') $\mathrm{X}$ to $\mathrm{Y}$ each 0.047 (positive) or no opposite with indirect effect (ab) with positive value $(0.561$ $=0.907 \times 0.618)$. It can be concluded both mediation model in this study are consistent and provide positive effect, therefore it could be decided to reject $\mathrm{H}_{0}$ and accept $\mathrm{H}_{1}$.

Furthermore, if seen from the value of the direct effect (coefficient c ) $\mathrm{X}$ to $\mathrm{Y}$ is -0.292 (negative), as opposed to the indirect effect (ab), is 0.250 (= $0.557 \times 0.448$ ) (positive), the mediation model in this study is inconsistent and gives negative effect. While the explanation of Figure 7 shows the results of the direct effect model of $\mathrm{X}$ to $\mathrm{Y}$ (c ') and there is a mediating effect $\mathrm{X}$ against $\mathrm{M}$ and $\mathrm{M}$ against $\mathrm{Y}$ (ab) is significant at the value of 0 (Table 10). Each direction of the influence is positive, so the model mediation is consistent.

The variable of the EGY dimension has an indirect relationship to SCF is ACT. The amount of indirect effect is $=0.907 \times 0.618=0.561$. In such circumstances the ACT variable functions as an intervening or mediating variable that can have an effect of $56.10 \%$ on the sustainability of community forests. In this case, reflective indicators can include the high and low efficiency of land use (EGY3) for timber plants managed by community forest farmers, which will indirectly affect poverty conditions around forest villages (SCF2). There is an intermediate variable indicator, namely post-harvest wood processing (ACT3), according to Sukwika et al. (2016), Apipoonyanon et al. (2020) and Tadesse and Teketay (2020) this condition shows that forest farmers' timber administration is highly dependent on the participation of farmers in increasing timber value added through post-harvest wood processing (above 80\% variant explained). Despite, the community forest program demonstrating direct results to livelihood improvement, more efforts are still needed to encourage alternative income sources to enable future generations to be less dependent on the forest (Ekanayake et al., 2020; Sukwika et al., 2020).

The total effect (TE) of EGY on SCF is 0.895. This value is obtained BY calculate: TE $=$ Path 1 (EGY SCF) + Path 2 (EGY ACT * 


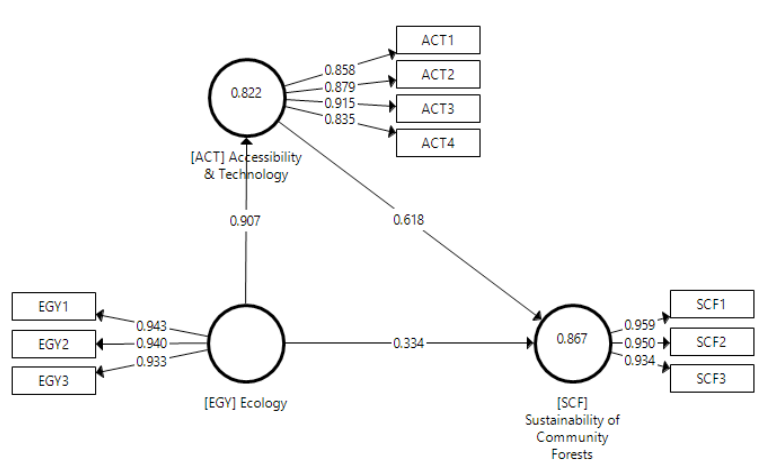

(a)

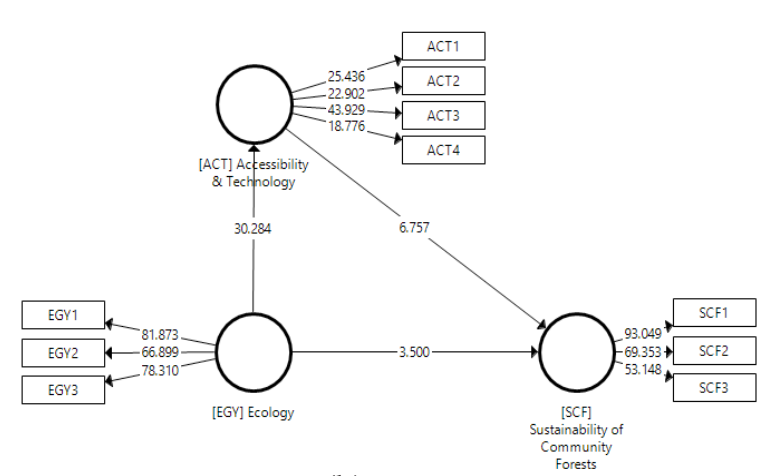

(b)

Figure 7. Diagram structural path of ecology to sustainability of community forests' result (a) trimming and (b) bootstrapping

ACT SCF $)=0.334+(0.907 \times 0.618)=0.334$ $+(0.561)=\mathbf{0 . 8 9 5}$. Thus, simultaneous policy intervention on the EGY dimension through its lever attribute does not necessarily give a positive effect or better than partially, or vice versa. That is, the choice of policy interventions for sustainable community forest management through the ecology dimension can use two approaches namely simultaneous and/or partial EGY-SCF indirect effect.

Baral et al. (2018) concluded that maintaining a large number of trees have direct effect to ecological but not on economical sustainability or play an indirect effect. Using exploratory factor analysis (EFA) and confirmatory factor analysis (CFA) Kusmana and Sukwika (2018) got results feasible in goodness of fit model, where the conservation activity can prevent the degradation area from erosion. However if it is to be utilized for economic activities by the community, it should be directed to the activities which are beneficial in preserving the environment or environmental services. Baral et al. (2018) and Sukwika et al. (2018) found linkage that rationalize annual harvests across all forest categories has a direct effect on improving resource conditions along with regular benefits to local communities.

\section{F. LIT and ACT Dimension Modelling}

Therefore, based on Figure 8, in this study, SCF model can be formed by more than one structural model and three Measurement model as follows: (1) Model of structural for latent variable LIT and ACT to SCF: $\eta \mathrm{SCF}=$

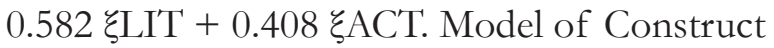
Measurement LIT, ACT, and SCF is:

$\left[\begin{array}{l}\text { ACT } 1 \\ \text { ACT } 2 \\ \text { ACT } 3 \\ \text { ACT } 4\end{array}\right]=\left[\begin{array}{l}0.850 \\ 0.882 \\ 0.882 \\ 0.838\end{array}\right] \eta_{\text {ACT }}$

(1) Measurement (ACT)

$\left[\begin{array}{l}\text { LIT1 } \\ \text { LIT2 } \\ \text { LIT3 } \\ \text { LIT4 }\end{array}\right]=\left[\begin{array}{l}0.924 \\ 0.945 \\ 0.955 \\ 0.929\end{array}\right] \eta_{\text {LIT }}$

(2) Measurement (LIT)

$$
\left[\begin{array}{l}
\text { SCF } 1 \\
\text { SCF } 2 \\
\text { SCF } 3
\end{array}\right]=\left[\begin{array}{l}
0.959 \\
0.951 \\
0.934
\end{array}\right] \eta_{\mathrm{SCF}}
$$

(3) Measurement (SCF)

Prediction of the value of an effect variable (endogenous) depends on the value of the independent variable (exogenous), this is because the prediction with path analysis is qualitative (Memon et al., 2018; Montoya, 2019; Namazi \& Navid-Reza, 2016; Nitzl et al., 2016). Variable of dimension LIT and ACT each of them has a positive direct effect to SCF with path coefficient value of 0.582 and 0.408 (Table 4). Both of the exogenous variable has the causal effect (significant) to endogenous 


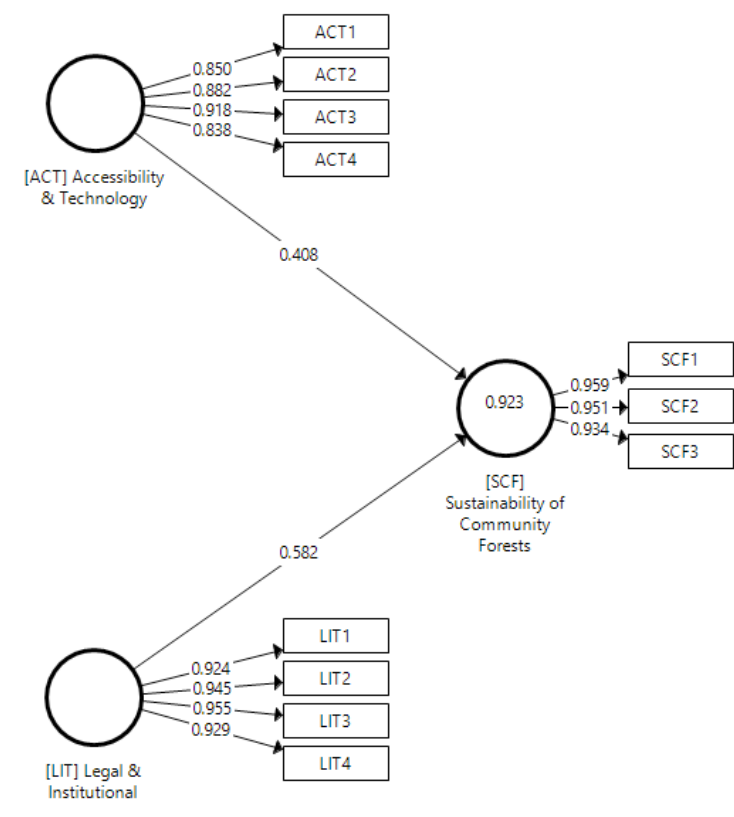

(a)

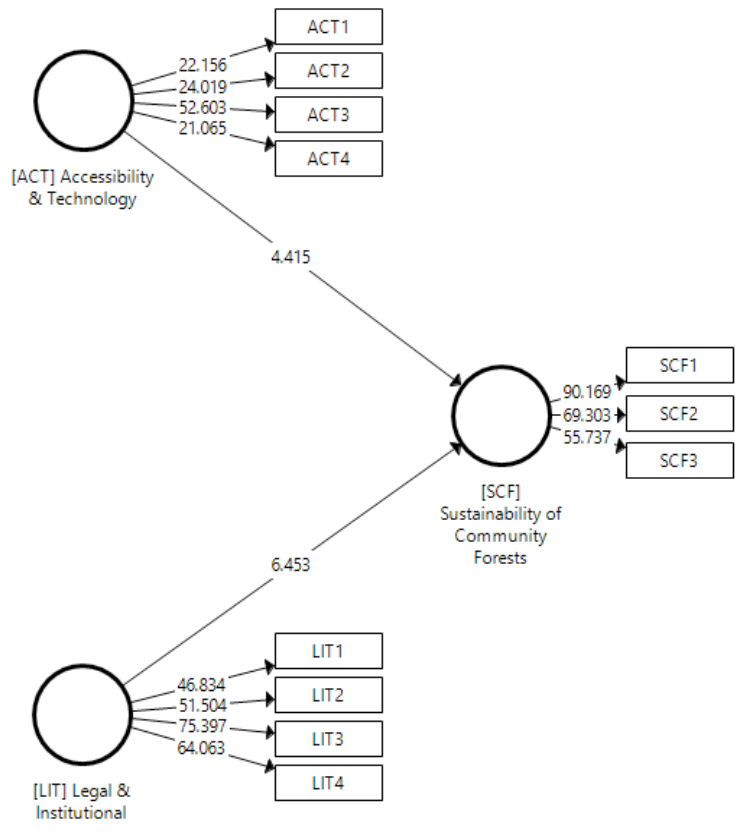

(b)

Figure 8. Diagram of structural path of LIT and ACT to sustainability of community forests result (a) trimming and (b) bootstrapping

variable SCF with probability value of $0(<$ $0.05)$ then it means sufficient data to reject $\mathrm{H}_{0}$ and accept $\mathrm{H}_{1}$.

This section does not discuss the mediational hypothesis for the causal steps strategy, because the fulfilment requirements are not available, independent variables (predictors) must significantly affect the mediator variables (MacKinnon et al., 2012; Sarstedt et al., 2017; Turnes \& Ernst, 2015; Ullman \& Bentler, 2013). Based on Figure 8 which shows that the variable LIT and ACT are exogenous variable (independent/predictor), so it does not have relations for an indirect effect to SCF. Therefore, the total effect value LIT and ACT is 0.582 and 0.408 .

According to the measurement results above, the socialization relationship by the extension team regarding sustainable forest management is hampered. There is a very low effect of the extension agent's role toward the perspective of forest farmers on the sustainability of community forests. Overall, institutional and accessibility influences on the sustainability of community forests are adequate and weak.
These obstacles can be influenced by different perspectives on sustainable forest management and a fragmented network of many different owners with a clear asymmetrical distribution of trust and power (Sukwika et al., 2020; Van Gossum et al., 2011). However, it is possible because the most powerful and trusted actors in the network - the forest group and the forest service - have the same perspective on sustainable forest management as the government (Van Gossum et al., 2011).

\section{G. Dominant Effect Between Multidimensional Variables}

In structural equations, to involve many variables and paths between variables, there are also relations of effects between variables which include, direct effects, indirect effects and total effects (Ghozali \& Latan, 2015b; Hair et al., 2014; Vinzi et al., 2010). Summary of variables which have that 3 (three) effects to variable SCF is shown in Table 4.

The indirect effect of the EGY to SCF dimension is 0.561 . It shows that the rise in the EGY dimension will have an impact on 
the increase in SCF as a result of the Ecology dimension. So the EGY dimension provides a total effect to SCF through other mediations, namely ACT, which is 0.895 . It means that each increase in the EGY dimension score by 100 $\%$ will increase the SCF score by $89.5 \%$. From Table 4 can be obtained the direct effect of ACT to SCF which is 0.408 .

Based on the calculation of total coefficient effect from each variable with the significant result to an endogenous variable (Table 4), it can be sorted as follows:

1. Total effect EGY to SCF $=0.895$ (strong: dominant)

2. Total effect ECO to SCF $=0.855$ (strong)

3. Total effect SOC to SCF $=0.825$ (strong)

4. Total effect LIT to SCF $=0.582$ (adequate)

5. Total effect ACT to SCF $=0.408$ (weak)

The dimension of EGY is a dominant effect variable or with a robust effect on SCF. This level is shown by EGY variable where the greatest total effect coefficient value is 0.895 . Figure 9 shows that simulation of total effect from dimensional variable to SCF variable. This simulation held resampling data test for 300 times reoccurrence by doing the bootstrapping technic (Afanadorac et al., 2013; Ghozali \& Latan, 2015b; Hair et al., 2019; Sarstedt et al., 2017; Thoemmes et al., 2010; Ullman \& Bentler, 2013). Sample in Figure 8 shows that one of the total effect variable EGY relations to SCF in Figure (a). The figure shows that the estimation result variety is between $0.815-0.950$ for its coefficient value. However, based on the simulation value, it shows the estimation coefficient with the frequency of occurrence above 15 between $0.875-0.925$ for its coefficient value. EGY variable, based on the average estimation of total coefficient effect value of EGY to SCF is 0.895 . This average value is the same with the value result of a calculation, refer to Table 4.

Forest farmer activities in planting, managing, developing, and sustainably utilizing plantation forests assist policy and decisionmakers, land use planners, environmental analysts, forest conservation and management experts to consider socio-economic, bio-physical, and institutional indicators that directly and indirectly effect the dependencies of local communities on forests and their levels of participation on management activities (Sukwika et al., 2018; Sukwika et al., 2020; Tadesse \& Teketay, 2020; Van Gossum et al., 2011).

Research experience has found the benefits of the analysis by using PLS-SEM i.e. it does not need a large sample size that can cover hundreds or even thousands, it can simply use few observations. This research experience was also proven by Kock (2014) who stated that a measure of the magnitude of an effect is independent of the size of the sample analyzed. Other research experiences by Goodhue et al. (2012) proved that the minimum sample size on the PLS-SEM test is capable of achieving an acceptable power level. While the Kock and Hadaya (2018) study has proven that the reliability of PSL-SEM using the inverse square root method and Monte-Carlo found that the inverse square root method is particularly attractive. The implications of the research results is consistent with these findings, it is our recommendation for PLS-SEM users to use the inverse square root method for minimum sample size estimation. By doing so, those researchers will generate estimates that are both fairly precise and safe, with both normal and non-normal data.

In 2012, Costa et al. compared the potential of PLS regression and ordinary linear regression for accurate modelling of forest work, with special reference to wood chipping, wood extraction and the continuous harvesting of short rotation coppice. Compared to linear regression, PLS regression allowed producing models that better fit the original data. By producing alternative models, PLS regression may provide additional - and not alternative - ways of reading the data. Ideally, a comprehensive data analysis could include both ordinary and PLS regression and proceed from their results in order to get a better understanding of the phenomenon under examination. 


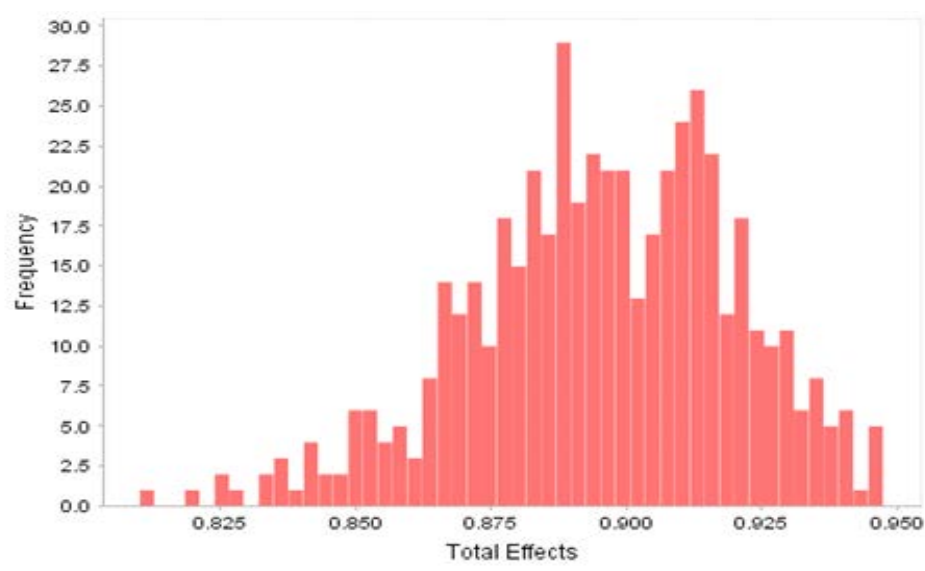

(a) EGY to SCF: strong (dominant)

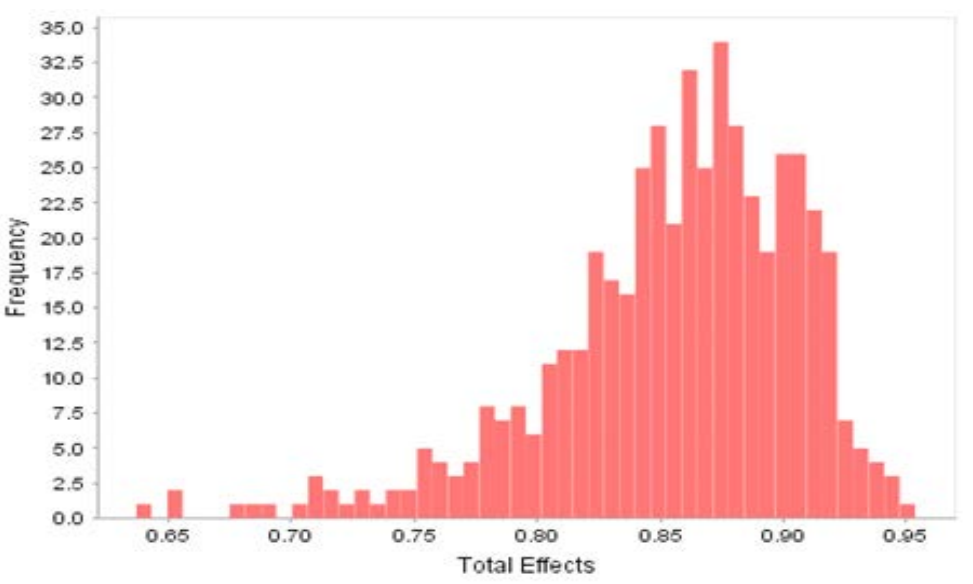

(b) ECO to SCF: strong

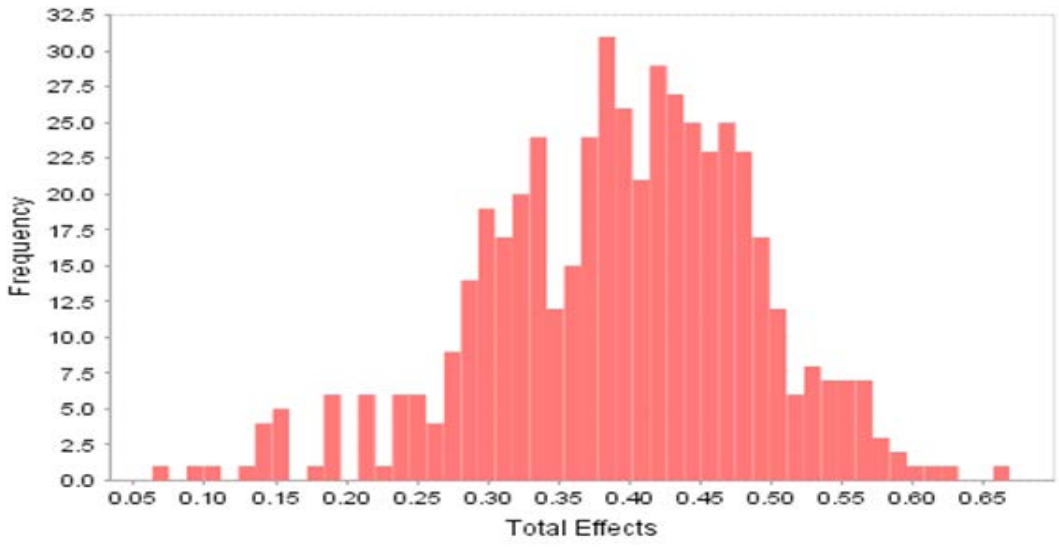

(c) ACT to SCF: weak

Figure 9. Diagram effect total variable dimensional to sustainability of community forests: (a) ecology, (b) economic, and (c) accessibility and technology 


\section{CONCLUSION}

Sustainability dimensions of economic, ecology, legal and institutional, and accessibility and technology have significant positive direct effect on sustainability of community forests. Therefore, the higher level of sustainability in economic, ecology, legal and institutional, and accessibility and technology, the better the sustainability of community forests, and viceversa. Meanwhile, the dimension of social has no significant direct effect on sustainability of community forests. The result of mediational hypothesis testing suggested that there is a partial mediation from economic and ecology to sustainability of community forests, which is consistent and have a positive effect. Meanwhile, there is a complete mediation from social to sustainability of community forests which is inconsistent and has a negative effect. Based on the calculation of the coefficient value of total effect (direct and indirect), among the five dimensions, Ecology has the biggest value (0.895). Therefore, it is concluded that ecology has the strongest effect on the sustainability of the community forest.

In contrast to the ecological dimension toward sustainable forest management, the contribution of the accessibility and technology dimension is weak, therefore, the policy implies that it is necessary to improve performance in an integrated manner in leveraging attributes of access to timber market information, logging method, and post-harvest wood processing. Other concrete actions are increasing farmer's participation to add value to timber and reducing poverty levels through the monthly income of farmers from non-timber forest products and agroforestry. Furthermore, related to institutions, the forestry office needs to improve the quality of agricultural and forestry extension program activities, namely through periodical improvement in planning for extension programs to forest farmer groups.

\section{ACKNOWLEDGEMENT}

We wish to thank forestry agencies and BP3K Bogor Regency, Ministry of Environment and Forestry, Natural Resources Conservation Centre (BKSDA) in Bogor who made this work possible. Special thanks to our friends, for their valuable work in the field collecting data and the many farmer's groups who participated in the survey. Finally, much more thanks to reviewers for their valuable comments to the manuscript.

\section{REFERENCES}

Afanadorac, N. L., Tranb, T. N., \& Buydensc, M. C. (2013). Use of the bootstrap and permutation methods for a more robust variable importance in the projection metric for partial least squares regression. Analytica Chimica Acta, 768, 49-56. doi://10.1016/j. aca.2013.01.004.

Ali, Z., \& Bhaskar, S. B. (2016). Basic statistical tools in research and data analysis. Indian Journal of Anaesthesia, 60(9), 662-669. doi://10.4103/0019-5049.190623.

AmirKhali, S. S. (2013). Predictive efficiency of random effects approach: A real model simulation study. Journal of Business \& Economics Research, 11(11), 1-6.

Apipoonyanon, C., Kuwornu, J. K. M., Szabo, S., \& Shrestha, R. P. (2020). Factors influencing household participation in community forest management: evidence from Udon Thani Province, Thailand. Journal of Sustainable Forestry, 39(2), 184-206. doi://10.1080/1054 9811.2019.1632211.

Baral,S., Gautam, A.P., \& Vacik,H. (2018). Ecological and economical sustainability assessment of community forest management in Nepal: A reality check. Journal of Sustainable Forestry, 37(8), 820-841. doi://10.1080/10549811.20 18.1490188.

Baron, R. M., \& Kenny, D. A. (1986). The moderator-mediator variable distinction in social psychological research: Conceptual, strategic, and statistical considerations. Journal of Personality and Social Psychology, 51(6), 1173-1182.

Bryman, A., \& Bell, E. (2007). The nature of qualitative research. In Business Research Methods (pp. 402-437). New York: Oxford University Press. 
Carrión, G. C., Nitzl, C., \& Roldán, J. L. (2017). Mediation analyses in partial least squares structural equation modeling: Guidelines and empirical examples. In H. Latan \& R. Noonan (Eds.), Partial Least Squares Path Modeling: Basic Concepts, Methodological Issues and Applications (pp. 173-195). Cham: Springer International Publishing.

Cham, H., West, S. G., Ma, Y., \& Aiken, L. S. (2012). Estimating latent variable interactions with non-normal observed data: a comparison of four approaches. Multivariate Behavioral Research, 47(6), 840-876. doi://10.1080/002 73171.2012.732901.

Chernick, M. R. (2011). Bootstrap methods: A guide for practitioners and researchers. New York: John Wiley \& Sons, Inc.

Cheung, G. W. \& Lau, R. S. (2007). Testing mediation and suppression effects of latent variables: Bootstrapping with structural equation models. Organizational Research Methods, 11(2), 296-325.doi://10.1177/1094428107300343.

Costa, C., Menesatti, P., \& Spinelli, R. (2012). Performance modelling in forest operations through partial least square regression. Silva Fennica, 46(2), 241-252.

Dawson, J. F. (2014). Moderation in management research: What, why, when, and how. Journal of Business and Psychology, 29(1), 1-19.

Eisingerich, A. B., \& Rubera, G. (2010). Drivers of brand commitment: A cross national investigation. Journal of International Marketing, 18(2), 64-79. doi://10.1509/jimk.18.2.64.

Ekanayake, E. M. B. P., Xie, Y., Ahmad, S., Geldard, R. P., \& Nissanka, A. H. S. (2020). Community forestry for livelihood improvement: Evidence from the intermediate zone, Sri lanka. Journal of Sustainable Forestry, 1-17. doi: //10.1080/10549811.2020.1794906.

Fritz, M. S., Taylor, A. B., \& Mackinnon, D. P. (2012). Explanation of two anomalous results in statistical mediation analysis. Multivariate Behavioral Research, 47, 61-87. doi://10.1080/00273171.2012.

G-Assembly. (2005). World summit outcome: Resolution adopted by the General Assembly on 16 September 2005. (A/RES/60/1). UN General Assembly Retrieved from https://www.un.org/at 18 September 2020

Ghozali, \& Latan. (2015a). Partial least squares Konsep, teknik, dan aplikasi menggunakan Program SmartPLS 3.0) untuk penelitian empiris. Semarang: Badan Penerbit Undip.
Ghozali, \& Latan. (2015b). Partial least squares: Concepts, techniques and applications using SmartPLS 3 (2 ed.). Semarang: Diponegoro University Press.

Goodhue, D. L., Lewis, W., \& Thompson, R. (2012). Does PLS have advantages for small sample size or non-normal data? MIS quarterly, 36(3), 981-1001. doi://10.2307/41703490.

Hair, J. F., Hult, G. T. M., Ringle, C., \& Sarstedt, M. (2016). A primer on partial least squares structural equation modeling (PLS-SEM): Sage Publications.

Hair, J. F., Ringle, C. M., \& Sarstedt, M. (2012). Partial least squares: the better approach to structural equation modeling? doi://10.1016/j.lrp.2012.09.011.

Hair, J. F., Ringle, C. M., \& Sarstedt, M. (2013). Partial least squares structural equation modeling: Rigorous applications, better results and higher acceptance. doi://10.1016/j. lrp.2013.01.001.

Hair, J. F., Risher, J. J., Sarstedt, M., \& Ringle, C. M. (2019). When to use and how to report the results of PLS-SEM. European Business Review, 31(1), 2-24. doi://10.1108/EBR-112018-0203.

Hair, J. F., Sarstedt, M., Hopkins, L., \& Kuppelwieser, V. G. (2014). Partial least squares structural equation modeling (PLS-SEM): An emerging tool in business research. European Business Review, 26(2), 106-121. doi://10.1108/EBR10-2013-0128.

Hair, J. F., Sarstedt, M., Ringle, C. M., \& Gudergan, S. P. (2017). Advanced issues in partial least squares structural equation modeling: SAGE Publications.

Hayes, A. F. (2013). Introduction to mediation, moderation, and conditional process analysis: A regression-based approach (1 $1^{\text {st }}$ ed.). New York: The Guilford Press.

Hayes, A. F., \& Rockwood, N. J. (2016). Regressionbased statistical mediation and moderation analysis in clinical research: Observations, recommendations, and implementation. Behaviour Research and Therapy, 98, 39-57. doi://10.1016/j.brat.2016.11.001.

Hayes, A. F., \& Scharkow, M. (2013). The relative trustworthiness of inferential tests of the indirect effect in statistical mediation analysis: Does method really matter? Psychological Science, 24, 1918-1927. doi://10.1177/0956797613480187. 
Holland, S. J., Shore, D. B., \& Cortina, J. M. (2016). Review and recommendations for integrating mediation and moderation. Organizational Research Methods, 20(4), 686720. doi://10.1177/1094428116658958.

Karazsia, B. T., Berlin, K. S., Armstrong, B., Janicke, D. M., \& Darling, K. E. (2013). Integrating mediation and moderation to advance theory development and testing. Journal of Pediatric Psychology, 39(2), 163-173. doi://10.1093/ jpepsy/jst080.

Kenny, D. A. (2008). Reflections on mediation. Organisational Research Methods, 11(2), 353358.

Kenny, D. A., \& Judd, C. M. (2014). Power anomalies in testing mediation. Psychological Science, 25(2), 334-339.doi://10.1177/0956797613502676.

Kock, N. (2014). Stable P value calculation methods in PLS-SEM. Laredo, TX: ScriptWarp Systems.

Kock, N., \& Hadaya, P. (2018). Minimum sample size estimation in PLS-SEM: The inverse square root and gamma-exponential methods. Information Systems Journal, 28(1), 227-261. doi://10.1111/isj.12131.

Kusmana, C., \& Sukwika, T. (2018). Coastal community preference on the utilization of mangrove ecosystem and channelbar in Indramayu, Indonesia. AACL Bioflux, 11(3), 905-918.

MacKinnon, D., Coxe, S., \& Baraldi, A. N. (2012). Guidelines for the investigation of mediating variables in business research. Journal of Business Psychology, 27, 1-14. doi://10.1007/ s10869-011-9248-z.

MacKinnon, D., Lockwood, C. M., Hoffman, J. M., West, S. G., \& Sheets, V. (2002). A comparison of methods to test mediation and other intervening variable effects. Psychological Methods, 7, 83-104.

Malhotra, N. K. (2017). Marketing research: An applied approach. Harlow: Pearson Education Limited.

Maslowsky, J., Jager, J., \& Hemken, D. (2015). Estimating and interpreting latent variable interactions: A tutorial for applying the latent moderated structural equations method. International journal of behavioral development, 39(1), 87-96. doi://10.1177/0165025414552301.

Memon, M. A., Cheah, J.-H., \& Ramayah, T. (2018). Mediation analysis issues and recommendations. Journal of Applied Structural Equation Modeling, 2(1), 1-9.
Montoya, A. K. (2019). Moderation analysis in two-instance repeated measures designs: Probing methods and multiple moderator models. Behavior Research Methods, 51(1), 6182. doi://10.3758/s13428-018-1088-6.

Muller, D. (2013). Design characteristics of virtual learning environments: A theoretical integration and empirical test of technology acceptance and is success research. Saarbrücken: Springer Gabler.

Munasinghe, M. (1992). Environmental economics and sustainable development. Paper presented at the UN Earth Summit, Rio de Janeiro.

Musyoki, J. K., Mugwe, J., Mutundu, K., \& Muchiri, M. (2016). Factors influencing level of participation of community forest associations in management forests in Kenya. Journal of Sustainable Forestry, 35(3), 205-216. doi://10.1080/10549811.2016.114 2454.

Namazi, M., \& Navid-Reza, N. (2016). Conceptual analysis of moderator and mediator variables in business research. Economics and Finance, 36, 540-554. doi://10.1016/S22125671(16)30064-8.

Nitzl, C., Roldan, J. L., \& Cepeda, G. (2016). Mediation analysis in partial least squares path modelling: Helping researchers discuss more sophisticated models. Industrial Management \& Data Systems, 116(9), 18491864. doi://10.1108/IMDS-07-2015-0302.

Paul, E. J. (2013). Doing statistical mediation and moderation (methodology in the social sciences) $\left(1^{\text {st }}\right.$ ed.). New York: Guilford Press.

Preacher, K., \& Hayes, A. (2008). Asymptotic and resampling strategies for assessing and comparing indirect effects in multiple mediator models. Behavior research methods, 40, 879-891. doi://10.3758/BRM.40.3.879.

Preacher, K. J., \& Hayes, A. F. (2004). SPSS and SAS procedures for estimating indirect effects in simple mediation models. Behavior Research Methods, Instruments, \& Computers, 36(4), 717731.

Sarstedt, M., Ringle, C. M., \& Hair, J. F. ( 2017). Partial least squares structural equation modeling. In C. H. e. al. (Ed.), Handbook of Market Research (pp. 41). New York: Springer International Publishing AG.

Singh, A. S., \& Masuku, M. B. (2014). Sampling techniques and determination of sample size in applied statistics research: An overview. International Journal of Economics, Commerce and Management, 2(11), 1-22. 
Sukwika, T., Darusman, D., Kusmana, C., \& Nurrochmat, D. R. (2016). Evaluating the level of sustainability of privately managed forest in Bogor, Indonesia. Biodiversitas, Journal of Biological Diversity, 17(1), 241-248. doi://10.13057/biodiv/d170135.

Sukwika, T., Darusman, D., Kusmana, C., \& Nurrochmat, D. R. (2018). Policy scenarios for managing of sustainability private-forests in Bogor regency. Journal of Natural Resources and Environmental Management, 8(2), 207-215. doi://10.29244/jpsl.8.2.207-215.

Sukwika, T., Yusuf, D. N., \& Suwandhi, I. (2020). The institutional of local community and stratification of land ownership in surrounding community forests in Bogor. Jurnal Manajemen Hutan Tropika, 26(1), 59-71. doi:10.7226/jtfm.26.1.59.

Taber, K. S. (2016). The use of cronbach's alpha: When developing and reporting research instruments in science education. Research in Science Education, 2(2), 1-24. doi://10.1007/ s11165-016-9602-2.

Tadesse, S. A., \& Teketay, D. (2020). Determinant factors predicting the dependencies of local communities on plantation forests and their levels of participation on management activities in Basona Worena District, Ethiopia. Journal of Sustainable Forestry, 39(8), 800-826. doi://10.1080/10549811.2020.173 0907.

Tenenhaus, M., Vinzi, V. E., Chatelin, Y. M., \& Lauro, C. (2005). PLS path modeling. Computational Statistics \& Data Analysis, 48(1), 159-205. doi://10.1016/j.csda.2004.03.005.

Thoemmes, F., MacKinnon, D. P., \& Reiser, M. R. (2010). Power analysis for complex mediational designs using Monte Carlo methods. Structural Equation Modeling, 17, 510-534.
Turnes, P. B., \& Ernst, R. (2015). Strategies to measure direct and indirect effects in multi-mediator models. Business Review, 14(10), 504-514. doi://10.17265/15371514/2015.10.003.

Ullman, J. B., \& Bentler, P. M. (2013). Structural equation modeling. In I. B. Weiner (Ed.), Handbook of Psychology (2 ${ }^{\text {nd }}$ ed., pp. 661-690). New York: John Wiley \& Sons, Inc.

Ursachi, G., Horodnic, I. A., \& Zait, A. (2015). How reliable are measurement scales? External factors with indirect influence on reliability estimators. Economics and Finance, 20, 679686. doi://10.1016/S2212-5671(15)001239.

Valentini, F., \& Damasio, B. F. (2016). Average variance extracted and composite reliability: Reliability coefficients. Psicologia: Teoria e Pesquisa, 32(2), 1-7. doi://10.1590/0102$3772 \mathrm{e} 322225$.

Van Gossum, P., Arts, B., De Wulf, R., \& Verheyen, K. (2011). An institutional evaluation of sustainable forest management in Flanders. Land use policy, 28(1), 110-123. doi://10.1016/j.landusepol.2010.05.005.

Vinzi, V. E., Chin, W. W., Henseler, J., \& Wang, H. (2010). Handbook of partial least squares: Concepts, methods and applications: Springer Publishing Company, Incorporated.

Yamane, T. (1967). Statistics: An introductory analysis $\left(2^{\text {nd }}\right.$ ed.). New York: Harper and Row.

Yzerbyt, V., Muller, D., Batailler, C., \& Judd, C. M. (2018). New recommendations for testing indirect effects in mediational models: The need to report and test component paths. Journal of Personality and SocialPsychology, 115(6), 929-943. doi://10.1037/pspa0000132. 